\title{
The Dilemmas of Christian Feminism
}

\begin{abstract}
The aim of the article is to discuss selected issues of Christian feminism which attempt to reconcile traditional women's roles in a society with the idea of emancipation. The article is composed of four parts. The first one discusses the basic theses of Christian feminism. The second one includes deliberations on biblical and theological evidence for women's and men's statuses. The third and fourth part offer an analysis of biblical examples of women's autonomy and the postulate of women's emancipation in the Christian work ethos.
\end{abstract}

\section{Keywords}

Bible, Christianity, egalitarianism, emancipation, feminism, theology.

\section{The essence of Christian feminism}

According to theologian, Rev. Ireneusz Mroczkowski, feminism was born together with the Enlightenment which brought about a break in the perception of freedom and religion. However, he believes that it is wrong to say that feminism negates the teachings of the Church in general and tries to make women independent from it. The theologian refers to the words of John Paul II who often mentioned this movement in his speeches, emphasising female greatness, which should be adequately appreciated and the dignity that should be respected. He was calling for the non-rejection of masculism and avoidance of deconstruction of social roles, simultaneously, putting emphasis on the reduction of discrimination, violence and inequality (which is a common feature of the Enlightenment and 
Christian feminism). ${ }^{1}$ Together with the so-called "new feminism”, the Christian thought incorporated feminist theology as the opposite to androcentric theology. It aims at proving the existence of bipolarity in each human being, thus, the presence of female and male elements in representatives of both genders without simultaneous negation of natural differences and predispositions. ${ }^{2}$ As in the case of „new feminism”, women's theology pursues Christian roots of the women's emancipation movement.

According to philosopher, Harriet Baber, many feminists currently speaking out about both philosophical and religious issues, argue whether rights, practices and doctrines which by definition are to be of a neutral world-view, are rooted in a male way of thinking and therefore male-biased. H. Baber mentions the opinion of feminist theologian, Rosemary Reuther, that the „official theological culture” characterised by men's domination and repressiveness towards women - is the result of the centuries-old women's deprivation of a possibility of leadership in a society and their exclusion from theological education. ${ }^{3} \mathrm{H}$. Baber believes that the necessity of thorough transformation and revision of Christian religion postulated by Reuther will eventually count against feminist interests. According to the mentioned researcher, this revision of the foundations of faith implicite contains the promotion of previous social and language structures disregarding women. ${ }^{4}$

Feminists are in step with the postulate of the necessity of improving women's lot; however, discrepancies in their opinions result from acknowledging different sources of „women's weakness”, as a consequence of men's domination. There are the stances emphasising that empirically noticeable differences in physical bodies of individuals of a different gender do not imply considerable differences in psyche as it has been previously assumed. Currently, many female researchers believe that there are differences between women and men, deeply rooted in the psychical structure, which are inborn or induced by childhood experiences.

1 I. Mroczkowski, Nowy feminizm, Fundacja Kobiety dla Kobiet, p. 1, http://www.femina. org.pl/index2.php?option=com_content\&do_pdf=1\&id=20 (16.05.2016).

${ }^{2}$ K. Białas-Zielińska, Teologia feministyczna a „nowy” feminizm. Zarys problematyki, p. 65, in: Varia Doctrinalia, Łukasz Machaj (ed.), Wrocław 2012, Uniwersytet Wrocławski, http:// www.bibliotekacyfrowa.pl/Content/41103/05_Klaudyna_Bialas_Zielinska.pdf (20.06.2016).

${ }^{3}$ H. E. Baber, Feminism and Christian Ethic, Department of Philosophy University of San Diego, p. 1, http://home.sandiego.edu/ baber/research/feminismchristianethics.pdf (19.05.2016).

${ }^{4}$ H. E. Baber, Feminism..., p. 2. 
Regardless of the origin of beliefs concerning gender differences, feminists highlight the fact of a common belief of the woman perceived as a weaker being. There is also a generally accepted opinion that Christian doctrine consolidates this hierarchisation through the total male domination in the structures of the Church authorities. Female followers of Christian feminism would like to emphasise aspects of equality in Christian theology by referring to the biblical records concerning freedom and equality of all people. In this case, the key argument is a claim that oppression and injustice experienced by women constitute a negation of the idea of human freedom and, thus, are contrary to God's will. $^{5}$

\section{Biblical testimonies of the equality between men and women}

In his book Evangelical Feminism and Biblical Truth, Evangelical theologian, Wayne Grudem analyses aspects of equality concerning the creation of man and woman on the basis of biblical scriptures. The author believes that every discussion on the difference between masculinity and femininity has to start with the Book of Genesis. According to this biblical book, a human being, regardless of his/her gender, manifests the Creator. Consequently, W. Grudem questions the interpretation of the Old Testament as a book promoting the idea of male dominance. The theologian claims that biblical wisdom should be an answer to all the contemporary signs of discrimination, violence and injustice towards women. These behaviours take place in almost every culture of the world, and the testimony of Christians should challenge them. ${ }^{6}$ The belief of one's subjection to the other found in Western culture is perceived by W. Grudem as „wrongful traditions", unconfirmed in God's testimony. The postulate of equal treatment of women and men is also included in the contents of the New Testament. Let us refer to the words of St. Paul, who proclaimed everyone's equality in Christ and condemned divisions. "There is neither Jew nor Gentile, neither slave nor free, nor is there male and female, for you are all one in Christ Jesus."

${ }^{5}$ K. Białas-Zielińska, Teologia feministyczna...

${ }^{6}$ W. Grudem, Evangelical Feminism and Biblical Truth, Published by Crossway 2004, pp. 26-27, http://www.wtsbooks.com/common/pdf_links/9781433532610.pdf (05.08.2016).

7 The Letter of St. Paul the Galatians 3:28, https://www.biblegateway.com/passage/?search $=$ Galatians $\% 203$ (12.07.2016). 
The egalitarian interpretation of the Scripture, recognised by some Christians, confirms the feminist postulates concerning equality of rights and emancipation. The statement concerning this subject - Men, Women and Biblical Equality - can be found on the website 'Christians for Biblical Equality.' ${ }^{8}$ These are the excerpts mentioned by W. Grudem in his book: "The Bible teaches that both man and woman were created in God's image, had a direct relationship with God, and shared jointly the responsibilities of bearing and rearing children and having dominion over the created order (Gen. 1:26-28). (...) The Bible teaches that the rulership of Adam over Eve resulted from the Fall and was, therefore, not a part of the original created order.... (...) The Bible defines the function of leadership as the empowerment of others for service rather than as the exercise of power over them (Matt. 20:25-28, 23:8; Mark 10:42-45; John 13:13-17; Gal. 5:13; 1 Pet. 5:2-3). (...) The Bible teaches that husbands and wives are heirs together of the grace of life and that they are bound together in a relationship of mutual submission and responsibility (1 Cor. 7:3-5; Eph. 5:21; 1 Pet. 3:1-7; Gen. 21:12). The husband's function as "head" (kephal $\Sigma$ ) is to be understood as self-giving love and service within this relationship of mutual submission (Eph. 5:21-33; Col. 3:19; 1 Pet. 3:7)."

In his theory, W. Grudem attempts to explain the stereotype of male dominance. The theologian advocates traditional roles but without bringing discredit up on the other human being, including a woman. When analysing the egalitarian approach, W. Grudem emphasises that different social roles, attributed to the representatives of different genders in the Bible, do not mean male supremacy over women. The theologian analyses the words of the Old Testament showing that the descendants of Adam and Eve should not do penance for the curse put upon the great parents by God. They should aim at improvement of their lot and reduction of the results of the curse - avoid hunger, soothe the pain of labour and minimize conflicts in marriages. ${ }^{10}$

W. Grudem gives an example of his marriage. He claims that he treats his wife as an equal, trustworthy and jointly responsible person. He does not consider himself as a better or wiser human being. Still, he thinks that, as a man, he has a responsibility bestowed by God upon him for the marriage and family.

${ }^{8}$ CBE International website: http://www.cbeinternational.org (17.10.2016).

9 W. Grudem, Evangelical Feminism..., pp. 29-30 or http://www.cbeinternational.org/ resources/statement/cbes-statement-men-women-and-biblical-equality (06.08.2016).

10 W. Grudem, Evangelical..., p. 40. 
Therefore, he has to make wise decisions in conflict situations of great importance to both spouses. However, this does not mean wife's subjection to her husband. ${ }^{11}$ In this interpretation of the Holy Scripture, a man is woman's support, called up by God to pursue His will. A wife, although she should also interpret and pursue God's will, is not burdened with this responsibility. Generally speaking, supremacy related to making final difficult decisions is a specific feature of acting as a team. This feature is attributed to a specific person, especially in the case of failure to reach a compromise. Without this leadership, a group could not function in a situation of conflict.

\section{Biblical examples and women's autonomy}

Elżbieta Adamiak, theologian and feminist, the author of Milcząca obecność [Silent Presence] emphasizes the biblical women in her texts, and describes their roles, which are often misrepresented by the contemporary interpreters of the Holy Scripture. The researcher aims at introducing contemporary women to the biblical examples of women's strength which would inspire Christian emancipationists. Her attention is focused on the figure of Eve who, according to the Book of Genesis, was created together with a man. Adamiak believes that the act of disobedience related to reaching out for the forbidden apple was dictated by the thirst for knowledge. ${ }^{12}$ This opinion was shared by Immanuel Kant who tried to find a symbolic meaning of the parable of the original sin. According to him, picking and tasting the apple was the first free choice which awakened the awareness of necessity of making independent decisions in life. The area of freedom is the area of humanity ${ }^{13}$ - in this interpretation, the attitude of Eve symbolizes the autonomy of a human being going beyond his/her animal nature.

E. Adamiak emphasizes that, contrary to common beliefs, biblical women are not silent - they speak, sing, pray and have a significant influence on the sequence of events through the act of giving birth. In the researcher's opinion,

${ }^{11}$ W. Grudem, Evangelical..., p. 42.

12 J. Podgórska, E. Adamiak, Zawsze druga, zawsze pierwsza. Rozmowa z katolicka feministka, czerwiec 2011, Tygodnik Polityka, http://www.polityka.pl/tygodnikpolityka/spoleczenstwo/1516100,1,rozmowa-z-katolicka-feministka.read (02.06.2016).

13 P. Szymaniec, Państwo i prawo w filozofii dziejów Immanuela Kanta, "Wrocławskie Studia Erazmiańskie Zeszyty Studenckie II”, Wrocław 2009, p. 33, http://www.repozytorium.uni.wroc. pl/Content/32192/0003.pdf (08.09.2016). 
the most feminized part of the Old Testament is the Book of Ruth describing the friendship of a mother-in-law (Jewish) and a daughter-in-law (Moabite, pagan), as well as discussing the issue of mixed marriages. Although other parts of the Old Testament forbid relationships with foreigners, the Book of Ruth shows this kind of relationship as a rightful one and thanks to it, in Christ's genealogy, foreign blood first appeared (Ruth is David's great grandmother). One should add to this that according to Rev. Paweł Stępien, the author of Komentarz do Księgi Rut [Commentary to the Book of Ruth], the history of Maobite woman was to consolidate the position of people, not of Jewish origin, believing in Yahweh. ${ }^{14}$

Let us return to the deliberations of the author of Milczaca obecność. Ruth the mother-in-law is a female embodiment of Job - after losing her husband and sons, she finds herself at the bottom of the social hierarchy and decides to return to the land of ancestors to die there. The daughter-in-law would not leave her side. Let us refer to the Old Testament's excerpt: But Ruth replied, "Don't urge me to leave you or to turn back from you. Where you go I will go, and where you stay I will stay. Your people will be my people and your God my God."15

E. Adamiak interprets this parable as a praise for women's friendship. ${ }^{16}$ What is more, in the Book of Ruth, one can find a change of behaviour socially attributed to a woman. Naomi, widow and mourning mother, expresses the immensity of her misfortune by emphasising her female role as mother and wife. She said to her daughters-in-law: "Return home, my daughters. Why would you come with me? Am I going to have any more sons, who could become your husbands? (...)It is more bitter for me than for you, because the Lord's hand has turned against me!" Due to the loss of her sons, Naomi feels socially undervalued, that is „empty”. In this case, she is discredited because of not being a mother or a wife anymore. Despite this fact, Ruth decides to stay with her mother-in-law and go to Bethlehem. None of them seeks a man; their relation is the only thing that counts.

This parable does not have an idea specific for the Judaic ethos of life woman's sacrifice for others. Although the female figures of the Book of Ruth make decisions which are not socially approved, their value consists in being

${ }^{14}$ P. Stępień, Komentarz do Ksiegi Rut, "Warszawskie Studia Teologiczne” XV (2002), p. 33, http://pwtw.pl/wp-content/uploads/wst/15/St\%C4\%99pie\%C5\%84\%20P.pdf (07.08.2016).

15 The Old Testament, The Book of Ruth, verse 16, https://www.biblegateway.com/passage/ ?search=Ruth+1 (23.08.2016).

${ }^{16}$ J. Podgórska, E. Adamiak, Zawsze druga, zawsze pierwsza... 
true to their own conscience and autonomy. The Moabite decides to convert and believe in Yahweh ${ }^{17}$ for love of her mother-in-law - she explicitly highlights the value of the mother-in-law's decisions and choices. To sum up, the Book of Ruth in the Old Testament includes several unconventional feminist themes concerning female independence, friendship and journeys.

Women in the Old Testament, describing the world dominated by men, often tooke up socially difficult challenges. An example here can be counteracting childlessness, which was considered a disgrace and a reason for exclusion in the Judaic culture. Sarah, Abraham's wife, persuaded her husband to have sexual intercourse with Hagar, the handmaiden. ${ }^{18}$ Leah and Rachel did the same towards their husband Jacob, competing which each other. Another biblical figure, named Tamar, fought for her place in a family and pretended to be a courtesan to give birth to offspring. These morally controversial methods constituted denial of passivity and subjection at that time. These were the acts of courage and determination in reaching the desired aim and life satisfaction. A similar activity was manifested by the above-mentioned Ruth and Naomi who sought that the Moabite remarried. Sometimes, God himself intervenes on women's behalf in the Old Testament, as in the case of Sarah, who was gifted with offspring in her old age. ${ }^{19}$ Let us also refer to the parables of the Old Testament in which women have something to say in relation to their marriage or stand out against husband's will (e.g. Rebecca ${ }^{20}$ ) despite the patriarchal social system they live in. This situation sometimes has an influence on the lot of the whole Jewish nation (e.g. the act of Bathsheba who enthroned her, not first-born son, Salomon, who officially had no right to exercise power). ${ }^{21}$ The childless, wealthy shunammite woman mentioned in the Second Book of Kings ${ }^{22}$ is the head of her family. The husband is totally subjected to her will and wishes which even concerns doing other men a favour.

17 J. Ciecierska, E. Adamiak, O kobietach, in: Fatimska Pani magazine, issue 02(46), 2013, p. 8, http://fatimskapani.cba.pl/nr46.pdf (09.09.2016).

${ }^{18}$ Chapter 15.

19 J. Slawik, O rolach kobiet w Starym Testamencie (Biblii Hebrajskiej), "Rocznik Teologiczny" (2012), p. 12, http://www.academia.edu/3631269/O_ROLACH_KOBIET_W_STARYM_ TESTAMENCIE_BIBLII_HEBRAJSKIEJ_(04.07.2016).

${ }^{20}$ Genesis 24.

21 J. Slavik, O rolach kobiet..., p. 14.

222 Kings, 4. 
Apart from family life, women in the Bible participate in social life - they happen to be judges and prophets (Deborah ${ }^{23}$, Huldah $^{24}$, Miriam ${ }^{25}$ ), woman-warriors $\left(\mathrm{Jael}^{26}\right.$ ), female rulers (Jezebel ${ }^{27}$, Athaliah ${ }^{28}$ ) or saviours of Jews (Esther). Although the main characters of stories described in the Old Testament are men, there are representatives of the female gender occurring in different spheres of the public life, who fight for their rights and contribute to social changes. Women are also proponents of God's will. Their actions are valued according to the same criteria as in the case of men's deeds. ${ }^{29}$ The Old Testament shows women in many roles which are representative of different historical periods of ancient Israel. ${ }^{30}$

\section{Women's emancipation postulate in Christian ethos of work}

Researcher Jill Robson, in The Way magazine concerning Christian spirituality, published Women, Religious and Christian Feminism, an article analysing her experiences and knowledge concerning women engaged in spreading the Christian faith. J. Robson attended a school managed by nuns and they were the first ones to show her models of independence, courage and resourcefulness. They managed the facility, taught and took care of female students, looked after buildings, garden and kitchen, travelled the world, studied and all this took place without participation of men. The Sister Superior had considerable standing and was widely respected. J. Robson described this nun as „woman sensu stricte", having generally acknowledged feminine attributes and, simultaneously, qualities of a leader. ${ }^{31}$ The article contains the feminist message concerning nuns who are commonly perceived as humble servants subjected to patriarchal

\footnotetext{
23 Judges 4.

242 Kings 22.

${ }^{25}$ Ex. 15.

${ }^{26}$ Judges 4.

271 Kings 16.

281 Kings 21.

29 J. Slavik, O rolach kobiet..., p. 19.

30 J. Slavik, O rolach kobiet..., p. 10.

${ }^{31}$ J. Robson, Women Religious and Christian Feminism, The Way Magazine, p. 91, http:// www.theway.org.uk/Back/s065Byrne.pdf (06.07.2016).
} 
authorities of the Church. By giving up starting a family they lose the attribute which is still significant in relation to the assessment of mature women's value in social consciousness. J. Robson shows nuns as strong women focused on self-realisation, putting the gospel into practice ${ }^{32}$, not mortifying and not focused solely on inner contemplation. To the above-mentioned author, these teachers of spiritual life became role models and encouragement to get to know Christian feminism and life stories of such women as Joan of Arc, Teresa of Ávila or Catherine of Sienna, being ahead of their time and joining the individual's autonomy with the idea of Christian predestination. ${ }^{33}$

Professor Rev. Wincenty Myszor believes that "today (...) women not only catch up with men but even gain the advantage over them in many domains (...); speak up for themselves claiming equal rights" and emphasizes that the idea of feminism was established in the environment of Christian European culture with the theological deliberations at its roots. ${ }^{34}$ As it has been repeatedly shown in this article, the anthropological Christian thought is based on the equality of all people towards God and the ethos of common work to the benefit of family and society. Traditional women's roles of mothers and wives confronted with the contemporary postulate of professional activity constitute a challenge for the Catholic Church. So far, its stance has been consistent with traditional, patriarchal interpretations of the Holy Scripture. The turning point was the pontificate of John Paul II who considered a woman to be equal to man both with regard to dignity and responsibility. Previously, in the 30s of the 20th century, Pope Pius XI announced in Casti connubii encyclical on marriage that wife's obedience towards her husband is a natural woman's role. ${ }^{35}$ John Paul II was clearly opposed to this opinion and contributed to the development of Christian feminism. Consequently, the significance of strong and independent women has increased in society together with acknowledgement of their ambitions related to execute social tasks and hold public offices. However, the Pope did not depreciate the traditional role of motherhood and taking care of a family,

32 J. Robson, Women Religious...

${ }^{33}$ J. Robson, Women Religious..., p. 92.

${ }^{34}$ W. Myszor, Chrześcijanie wobec świata. Zagadnienie kobiet w życiu pierwotnego Kościoła, "Śląskie Studia Historyczno-Teologiczne" XVII (1984), p. 237, http://www.wtl.us.edu.pl/e107_ plugins/wtl_ssht/index.php?numer=17\&str=237-245 (07.08.2016).

${ }^{35}$ U. Pękala, Ewolucja roli kobiety w Kościele katolickim w XX wieku - wnioski i kontrowersje, Aequalitas, Volume 1,2012, p. 1, http://aequalitas.ka.edu.pl/2012_v1/A_2012_vol_1_23_Pekala. $\operatorname{pdf}(24.08 .2016)$. 
but put it on a par with professional development. In his opinion, this would cause that women's social and cultural development "will be truly and fully human." ${ }^{36}$ To confirm this thesis let us refer to other words of John Paul II from Laborem exercens encyclical, praising the meaning of the ethos of work for the development of society: "This will come about more easily if [...] a renewed "theology of work" can shed light upon and study in depth the meaning of work in the Christian life and determine the fundamental bond between work and the family, and therefore the original and irreplaceable meaning of work in the home and in rearing children." ${ }^{37}$ In his opinion, respect for work done at home, especially the one concerning raising children, should be equal to the respect for professional work. The attitude of the Pope had a positive influence on women's position in society. Therefore, emphasising the equal value of women's and men's work by the Catholic Church constitutes a considerable support for emancipation movements.

\section{Bibliography}

Baber H. E., Feminism and Christian Ethic, Department of Philosophy University of San Diego, http://home.sandiego.edu/ baber/research/feminismchristianethics. pdf (19.05.2016).

Białas-Zielińska K., Teologia feministyczna a „nowy” feminizm. Zarys problematyki, in: Varia Doctrinalia, Ł. Machaj (ed.), Wrocław 2012, Uniwersytet Wrocławski, http://www.bibliotekacyfrowa.pl/Content/41103/05_Klaudyna_Bialas_Zielinska. pdf (20.06.2016).

Ciecierska J., Adamiak E., O kobietach, in: Fatimska Pani magazine, issue 02(46), 2013, http://fatimskapani.cba.pl/nr46.pdf (09.09.2016).

Grudem W., Evangelical Feminism and Biblical Truth, Published by Crossway 2004, http://www.wtsbooks.com/common/pdf_links/9781433532610.pdf (05.08.2016).

Jan Paweł II naucza - O rodzinie, Słabek P. (ed.), Kraków 2011, Wyd. M.

Mroczkowski I., Nowy feminizm, Fundacja Kobiety dla Kobiet, http://www.femina.org. pl/index2.php?option=com_content\&do_pdf=1\&id=20 (16.05.2016).

Myszor W., Chrześcijanie wobec świata. Zagadnienie kobiet w życiu pierwotnego Kościoła, „Śląskie Studia Historyczno-Teologiczne” XVII (1984), http://www.wtl.us.edu.pl/ e107_plugins/wtl_ssht/index.php?numer=17\&str=237-245 (07.08.2016).

\footnotetext{
${ }^{36}$ Jan Paweł II naucza - O rodzinie, P. Słabek (ed.), Kraków 2011, Wyd. M, p. 135.

${ }^{37}$ Familiaris consortio of Pope John Paul II, http://www.scborromeo.org/docs/familaris_ consortio.pdf (12.10.2016).
} 
Pękala U., Ewolucja roli kobiety w Kościele katolickim w XX wieku - wnioski i kontrowersje, Aequalitas, Volume 1, 2012, http://aequalitas.ka.edu.pl/2012_v1/A_2012_vol_1_23_ Pekala.pdf (24.08.2016).

Podgórska J., Adamiak E., Zawsze druga, zawsze pierwsza. Rozmowa z katolicka feministka, czerwiec 2011, Tygodnik Polityka, http://www.polityka.pl/tygodnikpolityka/ spoleczenstwo/1516100,1,rozmowa-z-katolicka-feministka.read (02.06.2016).

Robson J., Women Religious and Christian Feminism, The Way Magazine, http://www. theway.org.uk/Back/s065Byrne.pdf (06.07.2016).

Slawik J., O rolach kobiet w Starym Testamencie (Biblii Hebrajskiej), „Rocznik Teologiczny” (2012), http://www.academia.edu/3631269/O_ROLACH_KOBIET_W_STARYM_ TESTAMENCIE_BIBLII_HEBRAJSKIEJ_(04.07.2016).

Stępień P., Komentarz do Księgi Rut, „Warszawskie Studia Teologiczne” XV (2002), http:// pwtw.pl/wp-content/uploads/wst/15/St\%C4\%99pie\%C5\%84\%20P.pdf (07.08.2016).

Szymaniec P., Państwo i prawo w filozofii dziejów Immanuela Kanta, „Wrocławskie Studia Erazmiańskie. Zeszyty Studenckie II", Wrocław 2009, http://www.repozytorium.uni. wroc.pl/Content/32192/0003.pdf (08.09.2016).

The Letter of St. Paul the Galatians 3:28, https://www.biblegateway.com/passage/?search=Galatians\%203 (12.07.2016).

The Old Testament, The Book of Ruth, verse 16, https://www.biblegateway.com/passage/?search=Ruth+1 (23.08.2016).

CBE International website: http://www.cbeinternational.org (17.10.2016).

Familiaris Consortio of Pope John Paul II, http://www.scborromeo.org/docs/familaris_ consortio.pdf (12.10.2016). 